\title{
POLA PENALARAN PADA BAGIAN LATAR BELAKANG SKRIPSI MAHASISWA PROGRAM STUDI PETERNAKAN FAKULTAS PERTANIAN UNIVERSITAS BENGKULU TAHUN 2016
}

\author{
Andri Setiawan, Didi Yulistio, dan Gumono \\ Program Studi Pendidikan Bahasa Indonesia \\ Jurusan Pendidikan Bahasa dan Seni \\ FKIP Universitas Bengkulu \\ andri2396setiawan@gmail.com
}

\begin{abstract}
Abstrak
Tujuan Penelitian ini untuk mendeskripsikan pola penalaran pada bagian latar belakang skripsi mahasiswa Program Studi Peternakan Fakultas Pertanian Universitas Bengkulu tahun 2016. Peneliti menggunakan teori Toulmin mencakup enam unsur argumen, yaitu C (claim), pernyataan , G (ground) alasan atau bukti, W (warrant) pendukung, B (backing) pendukung tambahan, M (modal qualifier) kepastian pernyataan atau ukuran klaim, dan R (rebuttal) penyangkalan. Metode penelitian yang digunakan, yaitu deskripsi kualitatif. Data dalam penelitian ini berupa kalimat pada bagian latar belakang skripsi mahasiswa Program Studi Peternakan Fakultas Pertanian Universitas Bengkulu tahun 2016, yang berjumlah 20 data. Sumber data penelitian ini yaitu, skripsi mahasiswa Program Studi Peternakan Fakultas Pertanian tahun 2016 Universitas Bengkulu. Teknik pengumpulan data pada penelitian ini yaitu dokumentasi. Analisis data dengan langkah sebagai berikut (i) membaca teks, (ii) mengklasifikasikan teks, (iii) mengelompokkan data sesuai permasalahan, (iv) menganalisis data penelitian sesuai permasalahan, (v) interpretasi dan kualifikasi data sesuai masalah. Hasil penelitian ditemukan beberapa pola penalaran dengan variasinya. Pola tersebut adalah (1) pola II (C-G-W) dengan pola (C-G-W) dan (W-C-G), (2) pola III (C-G-W-B) dengan variasi pola (G-W-B-C), (G-W-C-B), dan (W-B-G-C), (3) pola IV (C-G-W-B-MQ) dengan variasi pola (W$B-C-M Q-G),(G-C-W-B-M Q)$, (W-C-MQ-G-B), (W-C-G-B-MQ), (W-B-G-C-MQ), (G-C-W-MQ-B), (G-W-C-B-MQ), (C-G-W-B-MQ) dan (G-C-MQ-W-B) (4) pola V (C-G-W-B-MQ-R) dengan variasi pola (C-W-G-B-MQ-R), (C-G-W-B-R-MQ), (G-C-W-R-B-MQ), (W-B-G-R-C-MQ), dan (W-G-B-C$\mathrm{R}-\mathrm{MQ}$ ).Variasi tersebut hanya terletak pada penempatan kalimat yang memiliki fungsi unsur argumentasi.
\end{abstract}

\section{Kata kunci: Pola penalaran, bagian latar belakang skripsi, teori Toulmin}

\begin{abstract}
This research aimed at describing the reasoning pattern in the background section of the students' thesis of live stock department Study Program of the Faculty of Agriculture of Bengkulu University in 2016. The researcher used the theory of Toulmin covering six argument elements, namely C (claim), statement, $G$ (ground) reason or evidence, W (warrant) supporters, B (backing) additional evidence, $M$ (capital qualifier) statement certainty or claim size, and $\mathrm{R}$ (rebuttal) denial. The research method used is descriptive qualitative. The data in this research was the sentences in the background section of the students' thesis of the Husbandry Study Program of Faculty of Agriculture, University of Bengkulu 2016 which amounts to 20 data. The data source of this research was the thesis of the students of Husbandry Study Program of Faculty of Agriculture in 2016 of Bengkulu
\end{abstract}


Skripsi merupakan salah satu karangan argumentasi yang memuat fakta dan data empiris yang mementingkan pola penalaran yang tepat agar karangan ilmiah yang dihasilkan dapat mengkaji, membahas, atau menganalisis, dan menghubung-hubungkan variabel yang dikaji sampai menghasilkan suatu simpulan yang baik. Berdasarkan hasil pengamatan peneliti, terhadap skripsi mahasiswa Program Studi Peternakan Fakultas Pertanian tahun 2016. Penalaran mahasiswa dalam menulis bagian latar belakang skripsi masih kurang, hal tersebut terlihat dari kemampuan mahasiswa menghubungkan proposisi dengan bukti untuk meyakinkan pembaca. Selain itu unsur argumentasi yang digunakan mahasiswa dalam menulis latar belakang skripsi masih belum lengkap seperti yang dikemukakan dalam teori Toulmin.

Unsur argumentasi yang lengkap menurut Toulmin (1984) terdiri dari unsur claim (pernyataan penulis), ground (Alasan atau Bukti), warrant (pendukung), backing (pendukung tambahan), modal qualifiers (ukuran kepatian), dan rebbutal (penyangkalan). Pola penalaran yang tertuang dalam setiap paragraf tidak mengandung semua unsur argumentasi yang membentuk suatu kesatuan yang padu. Padahal keenam unsur tersebut merupakan suatu tolok ukur untuk menentukan ketajaman suatu argumen, tidak lengkapnya keenam unsur tersebut menunjukan lemahnya pola penalaran dalam menulis skripsi. Seharusnya hal tersebut tersebut tidak terjadi oleh mahasiswa dalam mengungkapkan argumentasi dalam sebuah tulisan, karena aktivitas menulis telah ditumbuhkan di perguruan tinggi, dengan cara pemberian tugas berupa menulis karangan ilmiah yang berupa makalah, laporan, dan artikel dalam setiap semesternya.

Dengan demikian, dari permasalahan di atas, maka peneliti mengangkat penelitian yang berkaitan dengan pola penalaran pada bagian latar belakang skripsi mahasiswa S1 Program Studi Peternakan Fakultas Pertanian Universitas Bengkulu tahun 2016. Fokus penelitian pada bagian latar belakang karena latar belakang merupakan uraian gambaran awal yang melatarbelakangi penulis tentang hal-hal yang berkaitan penelitian yang akan dilakukan. Melalui kegiatan analisis pola penalaran ini dapat mengukur kemampuan bernalar mahasiswa tersebut dalam menulis latar belakang skripsi.

Penelitian ini penting karena pola penalaran sangat penting bagi kaum intelektual, mahasiswa sebagai salah satu kaum intelektual diharapkan mampu berpikir logis, terutama dalam menulis karya tulis ilmiah. Penalaran harus dikuasai oleh mahasiswa di perguruan tinggi, pasalnya kemampuan bernalar menjadi tolok ukur bagaimana cara berpikir. Karya ilmiah pada dasarnya perwujudan hasil penalaran mahasiswa.

\section{METODE}

Metode penelitian yang digunakan pada skripsi ini yaitu deskripsi kualitatif. Data dalam penelitian ini berupa hubungan antar kalimat pada bagian latar belakang skripsi mahasiswa Program Studi Peternakan Fakultas Pertanian Universitas Bengkulu tahun 2016. Jumlah data skripsi tahun 2016 sebanyak 45 skripsi dengan bidang keahlian yang berbeda. Dari data tersebut maka peneliti akan mengambil sampel untuk dijadikan data penelitian. Peneliti menggunakan sampel sampel bertujuan (probability sampling) dengan mengambil data sebanyak 20 data. Sumber data pada penelitian ini yaitu dari skripsi mahasiswa Program Studi Peternakan Fakultas Pertanian tahun 2016 di ruang baca Fakultas Pertanian Universitas Bengkulu. Teknik pengumpulan data pada penelitian ini yaitu dokumentasi. Dokumen 
bisa berbentuk tulisan, gambar, atau karyakarya menumental dari seseorang (Sugiyono, 2007:329). Dokumen yang dimaksud dalam penelitian ini yaitu skripsi mahasiswa Program Studi Peternakan Fakultas Pertanian Universitas Bengkulu tahun 2016. Instrumen penelitian ini menggunakan instrumen dengan pedoman lembar pencatatan dokumen. Pencatatan dokumen dilakukan dengan bantuan panduan analisis pola penalaran berdasarkan Teori Toulmin, untuk mendeskripsikan pola penalaran yang muncul pada latar belakang skripsi mahasiswa dengan menganalisis enam unsur argumentasi menggunakan teori Toulmin, yaitu C (Claim) pernyataan, G (ground) bukti, W (warrant) pendukung, B (backing) pendukung tambahan, $\mathrm{M}$ (modal qualifier) ukuran klaim, dan R (rebuttal) sanggahan/kekecualian. Analisis data dengan langkah sebagai berikut (i) membaca teks, (ii) mengklasifikasikan teks, (iii) mengelompokkan data sesuai permasalahan, (iv) menganalisis data penelitian sesuai permasalahan, (v) interpretasi dan kualifikasi data sesuai masalah. Hasil penelitian ditemukan beberapa pola penalaran dengan variasinya.

\section{HASIL DAN PEMBAHASAN}

Pola penalaran pada bagian latar belakang skripsi mahasiswa Program Studi Peternakan Fakultas Pertanian Universitas Bengkulu tahun 2016 yang ditemukan mencakup empat pola sebagai berikut.

\section{Pola Penalaran II (C-G-W)}

Pola C-G-W terdiri dari tiga elemen, yaitu claim (pernyataan penulis), ground (alasan atau bukti), dan warrant (pendukung). Berdasarkan hasil analisis peneliti, terdapat dua data yang termasuk ke dalam pola penalaran II dengan pola CG-W dan W-C-G. Berikut ini salah satu data yang termasuk pola II.
(C)Pencapaian kecukupan kebutuhan nutrisi terutama protein hewani pada masyarakat akan lebih efisien bila dilakukan dengan meningkatkan konsumsi pangan yang bersumber dari komoditi peternakan khususnya daging ayam ras (broiler). (G)Menurut Khoirunnisa (2008), daging ayam ras mudah diperoleh dan harganya cenderung lebih terjangkau oleh masyarakat.

(W) Meningkatnya kesadaran masyarakat mengenai kebutuhan mengkonsumsi makanan yang memiliki nilai gizi yang cukup, juga ikut mempengaruhi penigkatan jumlah permintaan serta kebutuhan masyarakat akan bahan makanan yang memiliki nilai protein yang cukup tinggi. Salah satunya adalah bahan makanan yang mengandung protein hewani yang berasal dari ayam yaitu berupa daging. Daging ayam merupakan jenis makanan bergizi yang sangat populer dikalangan mayarakat yang bermanfaat sebagai sumber protein hewani.

Dari data disebut pola II karena data di atas menunjukan terdapat tiga unsur argumentasi yaitu (C) Claim, (G) Ground, (W) dan Warrant yang saling berhubungan dan terdapat penanda kebahasaan yang menandakan ketiga unsur tersebut.

\section{a. Claim (Pernyataan Penulis)}

Terdapat penanda kebahasaan yang menunjukan unsur claim (pernyataan penulis), yaitu bila dilakukan dengan. Kata tersebut menunjukan ide dari penulis yang berkaitan dengan cara atau tindakan yang akan dilakukan oleh penulis.

b. Ground (Alasan atau Bukti)

Terdapat penanda kebahasaan yang menunjukan unsur ground (bukti atau alasan), yaitu mudah diperoleh dan juga terdapat pendapat ahli yang menguatkan pernyataan penulis. 


\section{c. Warrant (Pendukung)}

Terdapat penanda kebahasaan, yaitu salah satunya dan merupakan. Frasa salah satunya menunjukan hal yang lebih spesifik, dan kata merupakan menunjukan definisi yang memberikan informasi sebagai penguat claim dan ground.

\section{Pola Penalaran III (C-G-W-B)}

Pola penalaran III merupakan pola yang terdiri atas unsur argumentasi claim (pernyataan penulis), ground (alasan atau bukti), warrant (pendukung), dan backing (pendukung tambahan). Berdasarkan hasil analisis yang dilakukan oleh peneliti, peneliti menemukan terdapat tiga data yang termasuk pola III dengan pola (G-W-BC), (G-W-C-B), dan (W-B-G-C). Berikut penjelasan salah satu data yang merupakan pola penalaran III.

(G) Salah satu upaya untuk mengurangi deposisi lemak adalah dengan pemberian tanaman obat-obatan tradisional. Pemberian tanaman obatobatan tradisional selain berkhasiat untuk manusia, juga efektif dalam menurunkan deposisi lemak ayam broiler. Salah satu tanaman obat tersebut adalah jintan hitam (Habi et al., 2014).

(W) Nigella sativa atau yang dikenal dengan nama jintan hitam adalah tanaman herbal yang berasal dari daerah di sekitar laut Mediterania (Rouhou et al, 2007). Jintan hitam kaya akan asam lemak tak jenuh ganda, berperan penting untuk kesehatan manusia. Jintan hitam membantu mengatur metabolisme, membawa racun ke permukaan kulit untuk dieliminasi, menyeimbangkan tingkat insulin, mengatur kolesterol, meningkatkan sirkulasi tubuh dan meningkatkan fungsi hati yang sehat (Salama, 2010).

(W)Hasil akhir yang diperoleh dari pengolahan jintan hitam adalah minyak dan limbah. Minyak jintan hitam digunakan untuk kebutuhan manusia sedangkan limbahnya belum manfaatkan oleh pihak industri rumah tangga yang mengolah biji jintan tersebut. Limbah jintan diperoleh dari salah satu industri rumah tangga pengolah minyak herbal Habbatussauda yang terdapat di Jakarta. Bentuk dari limbah itu sendiri berbentuk serpihan.

(B) Limbah Jintan hitam mengandung bahan kering $92 \%$, bahan organik 90,4\%, protein kasar 33,8\%, serat kasar 5,2\%, lemak 14,2\%, energi $2691 \mathrm{kkal} / \mathrm{kg}$ (El-Natta, 2007). Kandungan asam amino esensial limbah jintan hitam (Nigela sativa) yaitu threonin 1,45 \%, valine 0,04\%, methionine $0,55 \%$, isoleucine $1,42 \%$, leucine 2,44\%, phenylalanine 1,69\%, histidine $1,42 \%$, lysine $1.48 \%$, arginine $3,24 \%$, dan untuk kandungan asam amino nonesensial yaitu aspartic acid 2,97\%, serine $I, 35 \%$, glutamic acid $6,22 \%$, glysine $1.28 \%$, alanine $1,74 \%$, cystine 5,28\%, tyrosine $1.69 \%$ (ElRahman et al., 2011).

(C) Berdasarkan uraian tersebut penulis melakukan penelitian lebih lanjut tentang pengaruh pemberian limbah jintan hitam terhadap deposisi lemak ayam broiler.

Data di atas, termasuk ke dalam pola penalaran IV, karena data di atas menunjukan terdapat empat unsur argumentasi yaitu (C) claim, (G) ground, (W) warrant, dan (B) backing, serta terdapat penanda kebahasaan yang menandakan empat unsur tersebut.

\section{a. Claim (Pernyataan Penulis)}

Terdapat penanda kebahasaan yang menunjukan claim (pernyataan penulis), yaitu frasa berdasarkan uraian tersebut dan melakukan. Unsur kebahasaan tersebut menujukan kesimpulan yang disampaikan oleh penulis, dan kata melakukan merupakan penanda kebahasaan yang 
menujukan tindakan yang akan dilakukan penulis.

\section{b. Ground (Alasan atau Bukti)}

Terdapat penanda kebahasaan yang menunjukan unsur ground (bukti atau alasan), yaitu salah satu, untuk, adalah. Frasa tersebut memberikan landasan atau dasar dari claim (pernyataan penulis) yang berupa pendapat pakar terkait upaya khasiat obat-obatan tradisional.

\section{c. Warrant (Pendukung)}

Terdapat penanda kebahasaan, yaitu menunjukan warrant, yaitu adalah, dan berperan penting, digunakan untuk dan juga diperkuat dengan pendapat ahli. Penanda kebahasaan tersebut berisi informasi dan manfaat jintan hitam (tanaman herbal). Dengan penanda-penanda kebahasaan tersebut memperkuat dan medukung pernyataan penulis.

\section{d. Backing (Pendukung Tambahan)}

Terdapat penanda kebahasaan, yaitu klausa mengandung bahan. Pada berisi kalimat yang menguatkan unsur warrant yang telah diungkapkan pada paragraf sebelumnya dan backing (dukungan tambahan) tersebut berisi data berupa data persentase kandungan limbah jintan hitam yang diungkapkan oleh pendapat ahli dari El-Rahman et al., 2011 dan Habi et al. (2014).

\section{Pola Penalaran IV (C-G-W-B-MQ)}

Pola penalaran ini selain terdiri atas unsur argumentasi claim (pernyataan penulis), ground (alasan atau bukti), warrant (pendukung), backing (pendukung tambahan) dan unsur modal qualifiers (ukuran kepastian claim). Berdasarkan hasil analisis yang dilakukan oleh peneliti, peneliti menemukan terdapat sembilan data yang termasuk pola IV, dengan pola sebagai berikut: (W-B-C-MQ-G), (G-C-W-B$M Q),(W-C-M Q-G-B),(W-C-G-B-M Q)$, (W-BG-C-MQ), (G-C-W-MQ-B), (G-W-C-B-MQ),
(C-G-W-B-MQ) dan (G-C-MQ-W-B). Pola ini merupakan pola yang paling banyak ditemukan peneliti di bagian latar belakang skripsi mahasiswa Program Studi Peternakan Fakultas Pertanian 2016 Universitas Bengkulu.

Berikut penjelasan salah satu data yang merupakan pola penalaran IV.

(G)Daging dan ikan merupakan bahan makanan sumber protein hewani yang mudah mengalami kerusakan oleh aktivitas mikro organisme perusak pangan. Mikrobia perusak pangan diantaranya adalah Staphylococcus aureus, Bacillus subtilis, Bacillus cereus Pseudomonad, Stafilococcus, Micrococcus, dan Enterococcus (Fardiaz, 1995). (C) Upaya pengawetan perlu dilakukan agar pangan aman dan layak dikonsumsi. Pengawetan dapat dilakukan dengan pendinginan, penambahan zat kimia, iradiasi. (W)Usaha pengawetan diatur oleh undang-undang yaitu SK Menkes RI No. 722 tahun 1988 yang menegaskan bahwa pengawetan makanan diperbolehkan asal memenuhi peraturan yang ditetapkan. Pada peraturan tersebut dinyatakan bahwa penggunaan formalin di dalam makanan dilarang karena pertimbangan faktor keamanan dan kesehatan konsumen (Depkes-RI, 2006).

(MQ)Mengingat akan bahaya penggunaan formalin tersebut maka perlu usaha untuk menemukan bahan pengawet dari bahan yang alami. (B) Hasil beberapa penelitian menunjukan bahwa rempah-rempal dan bumbu asli Indonesia temyata banyak mengandung zat aktif anti mikrobia yang berpotensi untuk dijadikan sebagai pengawet alami, diantaranya adalah lengkuas, kunyit dan jahe. Kandungan minyak atsiri pada lengkuas dan jahe telah dibuktikan mempunyai sifat anti mikrobia (Taechoet al. 2004). Salah satu 
bahan tambahan pada sayuran yaitu bunga Kecombrang dapat digunakan sebagai bahan pengawet makanan. Menurut Naufalin (2005), bunga Kecombrang (Etlingera elatior) merupakan salah satu alternatif pengawet alami, karena kandungan komponen bioaktif yaitu alkaloid, polifenol, flavonoid, dan minyak atsiri.

Data atas termasuk ke dalam pola penalaran IV, karena data di atas menunjukan terdapat lima unsur argumentasi yaitu (C) claim, (G) ground, (W) warrant, (B) backing, dan (MQ) modal qualifiers.

\section{a. Claim (Pernyataan Penulis)}

Terdapat penanda kebahasaan, yaitu frasa perlu dilakukan dan dapat dilakukan. Frasa tersebut memberikan penegasan bahwa upaya pengawetan perlu dilakukan dan penulis mengukapkan cara atau tindakan yang akan dilakukan oleh penulis.

b. Ground (Alasan atau Bukti)

Terdapat penanda kebahasaan yang menunjukan ground (alasan atau bukti), yaitu merupakan. Kata tersebut memberikan penjelasan spesifik tentang daging dan ikan, penjelasan tersebut juga dikuatkan dengan kutipan dari ahli, yaitu Fardiaz, 1995

c. Warrant (Pendukung)

Dalam kalimat tersebut terdapat undang-undang yang berfungsi untuk memperkuat pernyataan penulis. Dengan undang-undang tersebut akan mendukung unsur claim dan ground, karena hal relevan dengan pernyataan yang telah diungkapkan oleh penulis. Undang-undang bersumber dari Depkes-RI, 2006.

\section{d. Backing (Pendukung tambahan)}

Terdapat hasil penelitian yang diambil dari (Taechoet al. 2004), yang dapat dijadikan sebagai dukungan tambahan untuk memperkuat pernyataan penulis, setelah itu terdapat penanda kabahasaan yang menunjukan unsur backing, yaitu mengandung zat aditif , berpotensi untuk, telah dibuktikan mempunyai. Frasa dan klausa yang terangkai dalam kalimat tersebut akan meyakinkan pembaca dan unsur backing ini akan memperkuat pernyataan penulis dan terdapat pendapat ahli yaitu ditandai dengan penanda bahasa, yaitu menurut Naufalin (2005).

\section{e. Modal Qualifier (Ukuran Kepastian)}

Terdapat unsur modal qualifiers yang terlihat dari indikator kata, frase atau keterangan yang digunakan sebagai penanda kepastian (modal qualifier) tersebut yaitu maka perlu.

\section{Pola Penalaran V (C-G-W-B-MQ-R)}

Pola argumen yang terakhir ini merupakan pola paling kompleks karena semua argumen tercakup di dalamnya. Pola penalaran $V$ ini terdiri dari kelengkapan unsur argumentasi unsur claim (pernyataan penulis), ground (alasan atau bukti), warrant (pendukung), backing (pendukung tambahan), modal qualifiers (ukuran kepastian claim), dan unsur rebuttal (penyangkalan). Berdasarkan hasil analisis yang dilakukan oleh peneliti, peneliti menemukan terdapat enam data yang termasuk pola $V$, dengan pola yaitu: (C-W-G-B-MQ-R), (C-G-W-B-R-MQ), (G-CW-R-B-MQ), (W-B-G-R-C-MQ), dan (W-G-BC-R-MQ).

Berikut penjelasan salah satu data yang merupakan pola penalaran $\mathrm{V}$.

(C) Usaha untuk mempertahankan kualitas daging broiler sangatlah perlu dilakukan melalui penanganan pasca panen sehingga dapat memperpanjang lama penyimpanan dari bahan pangan. (G) Afrianti (2008), menyatakan bahwa salah satu penanganan setelah pemotongan ternak adalah penyimpanan dapat mempengaruhi kualitas daging. merupakan media yang 
sangat baik untuk pekembangan mikroba patogen yang sampai saat ini tetap menjadi masalah kesehatan masyarakat, karena dapat menyebabkan penyakit jika terjadi kesalahan dalam penanganan seperti pemasakan atau penyimpan produk.

(W) Surajadi (2004). Usaha yang dapat dilakuan untuk mengedalikan terjadinya kerusakan dan perkembangan mikoba adalah dangan melakukan usaha pengawetan dengan bahan-bahan salah satu cara untuk menjaga kualitas daging pangan adalah dengan menambahkan bahan aditif berupa zat antimikroba dalam bentuk rempah-rempah, kimia maupun bahan alami yang memiliki sifat antimikroba.

(W) Tanaman andaliman mengandung senyawa terpenoid yang mempunyai aktivitas antioksidan yang sangat bermanfat bagi kesehatan dan berperan penting untuk mempertahankan mutu produk pangan (pengawetan) dari berbagai kerusakan seperti ketengikan, perubahan nilai gizi serta perubahan warna dan aroma makanan. Selain itu senyawa terpenoid pada andaliman juga dapat dimanfaatkan sebagai antimikroba. Hal ini memberikan peluang bagi andaliman sebagai bahan baku senyawa antioksidan atau antimikroba bagi industri pangan dan farmasi (Siregar 2002). (B) Hasil penelitian Suryanto (2004), membuktikan bahwa penggunaan larutan buah andaliman pada perlakuan 30\%, dapat mengawetkan ikan jembal selama 44 hari dan dapat mempertahan kualitas ikan jempal. Hasil penelitian Tarigan (1999), membuktikan bahwa kandungan terpenoit dari buah andaliman menpunyai aktivitas antioksidan dan antimikroba, juga mempunyai efek Imunostimulan, hal ini membuktikan bahwa buah andaliam sebagai senyawa antioksidan dan antimikroba. (R) Namun apakah kandungan buah andaliman juga dapat digunakan sebagai pengawet karena tepung biji andaliman belum pernah digunakan hingga saat ini belum dilakukan. Berdasarkan hal tersebut diatas maka perlu dilakukan penelitian tentang Pengaruh pemberian larutan tepung biji andaliman (Zantinyulumacanthopodium DC), Sebagai pengawet daging ayam broiler terhadap daya simpan, nilai $\mathrm{pH}$, dan uji sifat organoleptik.

Data dalam bagian latar belakang skripsi di atas termasuk ke dalam pola penalaran V, karena data di atas menunjukan kelengkapan unsur argumentasi yang terdiri dari (C) claim, (G) ground, (W) warrant, (B) backing, (MQ) modal qualifiers, dan rebuttal yang saling berhubungan.

\section{a. Claim (Pernyataan Penulis)}

Terdapat penanda kebahasaan unsur claim, yaitu frasa sangatlah perlu dilakukan melalui dan sehingga dapat. Frasa tersebut menunjukan cara atau tindakan yang akan dilakukan oleh penulis dan menujukan hal yang akan diperoleh dari tindakan yang akan dilakukan.

b. Ground (Alasan atau Bukti)

Terdapat penanda kebahasaan yaitu, salah satu dan karena. Ground (bukti) tersebut memberikan penjelasan spesifik yang ditandai dengan penanda kebahasaan, yaitu salah satu dan alasan, hal ini terlihat dari penanda kebahasaan yaitu, karena. Ground (bukti atau alasan) tersebut juga diperkuat dengan pendapat ahli yang ditandai dengan klausa Afrianti (2008), Menyatakan.

\section{c. Warrant (Pendukung)}

Terdapat penanda kebahasaan yang menunjukan unsur warrant (pendukung), yaitu frasa dapat dilakukan untuk, adalah dengan, salah 
satu. Frasa tersebut menunjukan bahwa penulis menyampaikan solusi yang diperkuat dengan pendapat ahli. Pada paragraf ketiga disebut warrant (pendukung) karena terdapat penanda kebahasaan yang menunjukan warrant (pendukung), yaitu sangat bermanfaat, berperan penting, juga dapat dimanfaatkan sebagai. Frasa tersebut menunjukan bahwa terdapat peran dan manfaat dari tanaman andaliman. Warrant (pendukung) ini berupa pendapat dari ahli Surajadi, 2004 dan Siregar, 2002.

\section{d. Backing (Pendukung Tambahan)}

Terdapat hasil penelitian ahli, yaitu Suryanto (2004), dan terdapat penanda kebahasaa, yaitu frasa membuktikan bahwa. Dari frasa membuktikan bahwa tersebut memberikan penegasan bahwa penelitian tersebut telah terbukti kebenaranya. Backing (pendukung tambahan) yang disampaikan tersebut menujukan bukti-bukti yang mendukung ditujukan melalui hasil penelitian Suryanto (2004).

\section{e. Modal Qualifier (Ukuran Kepastian)}

Terdapat indikator kata, frase atau keterangan yang digunakan sebagai penanda kepastian tersebut yaitu, maka perlu dilakukan. Penulis menegaskan claim dengan memberikan unsur modal qualifier. Adanya unsur modal qualifier tersebut untuk menekankan bahwa penelitian ini perlu dilakukan.

\section{f. Rebbutal (Penyangkalan)}

Dalam rangkaian kalimat tersebut menyampaikan kelemahan dari claim, penanda yang menunjukan rangkaian kalimat tersebut, menunjukan rebbutal (penyangkalan pada claim) yaitu terdapat kata namun. Kata namun memberikan menandakan adanya penyangkalan atau bantahan terhadap claim (pernyataan penulis) yang telah diungkapkan.

Berdasarkan uraian di atas maka disimpulkan pola penalaran pada bagian latar belakang skripsi mahasiswa Program Studi Peternakan Fakultas Pertanian Universitas Bengkulu tahun 2016 mencakup empat pola, yakni pola II, pola III, pola IV, dan pola V. Pola yang tidak ditemukan, yaitu pola I karena pola I merupakan pola yang cukup sederhana.

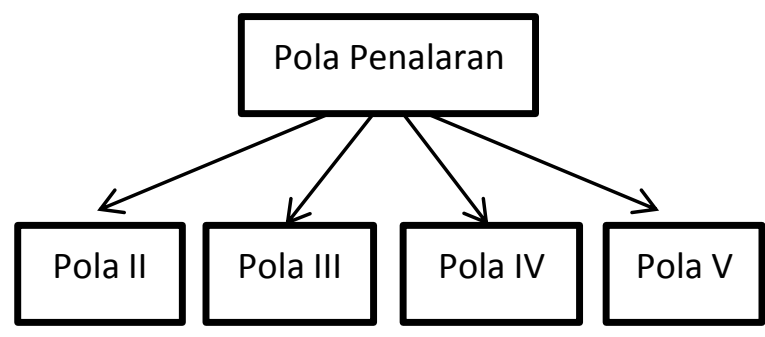

Pola penalaran yang ditemukan peneliti sesuai dengan Toulmin, Rieke, dan Janik (1984:25) mengungkapkan terdapat enam unsur argumentasi, yaitu C (claim) pernyataan, $\mathrm{G}$ (ground) alasan atau bukti , W (warrant) pendukung, B (backing) pendukung tambahan, $M$ (modal qualifier) ukuran kepatian klaim, dan R (rebuttal) penyangkalan, yang akan membentuk suatu pola, akan tetapi pola yang ditemukan peneliti tidak runtut seperti teori Toulmin, penulis memiliki gaya penulisan yaang berbeda tetapi itu hanya pola penulisannya saja, dan fungsi setiap elemen argumentasi tetap sama seperti yang dikemukakan oleh Toulmin. Pola penalaran yang ditemukan peneliti sesuai dengan teori Toulmin, Rieke, dan Janik (1984:40-90) mengungkapkan bahwa pola penalaran argumen tersebut, yakni I (C-G), pola II (C-G-W), pola III (C-G-W-B), pola IV (C-G-W-B-MQ), dan pola V (C-G-W-B-MQR). Pola penalaran yang tidak ditemukan peneliti yaitu pola I (C-G). 


\section{PENUTUP}

Kesimpulan

Berdasarkan hasil penelitian di atas dapat disimpulkan bahwa pola penalaran pada bagian latar belakang skripsi mahasiswa Program Studi Peternakan Fakultas Pertanian Universitas Bengkulu tahun 2016, ditemukan pola menurut empat pola penalaran yakni:

(1) Pola II, pola yang terdiri atas tiga unsur argmentasi, yaitu claim, ground, dan warrant, dengan pola (C-G-W) dan (W-CG). (2) pola III, pola yang terdiri atas empat unsur argmentasi, yaitu claim, ground, warrant dan backing, dengan variasi pola III (G-W-B-C), (G-W-C-B), dan (W-B-G-C). (3) Pola IV, pola yang terdiri atas lima unsur argmentasi, yaitu claim, ground, warrant, backing dan modal qualifier, dengan variasi pola IV, yaitu: (W-B-C-MQ-G), (G-C-W-B$M Q),(W-C-M Q-G-B),(W-C-G-B-M Q)$, (W-BG-C-MQ), (G-C-W-MQ-B), (G-W-C-B-MQ), (C-G-W-B-MQ) dan (G-C-MQ-W-B). (4) Pola $\mathrm{V}$, pola yang terdiri atas unsur argmentasi yang lengkap yaitu, claim, ground, warrant, backing, modal qualifier dan rebbutal, dengan variasi pola $V$, yaitu: (C-W-G-B-MQ$R$ ), (C-G-W-B-R-MQ), (G-C-W-R-B-MQ), (WB-G-R-C-MQ), dan (W-G-B-C-R-MQ).

Pola yang ditemukan peneliti tidak runtut seperti teori Toulmin, penulis memiliki gaya penulisan yaang berbeda tetapi itu hanya pola penulisannya saja, dan fungsi setiap elemen argumentasi tetap sama seperti yang dikemukakan oleh Toulmin. Selain melihat pola penalaran tersebut, peneliti juga melihat masih ada beberapa kesalahan penalaran dalam pada bagian latar belakang mahasiswa Peternakan Fakultas Pertanian Universitas Bengkulu, dan hal tersebut harus lebih diperhatikan oleh setiap mahasiswa sebagai kaum intelektual dalam kegiatan menulis akademis.

\section{Saran}

Berdasarkan hasil simpulan dan pembahasan yang telah dilakukan, maka penulis mengajukan saran sebagai berikut:

1. Bagi mahasiswa, hasil penelitian ini diharapkan dapat dijadikan masukan dan menambah informasi serta sebagai acuan perbaikan dalam melakukan pola penalaran pada menulis skripsi agar kegiatan menulis mahasiswa menjadi semakin baik.

2. Bagi dosen, hasil penelitian ini diharapkan dapat membantu dalam menghadapi permasalahan dalam menulis skripsi.

3. Bagi peneliti lain, penelitian ini mengenai pada pola penalaran pada bagian latar belakang skripsi mahasiswa. Peneliti berharap akan ada penelitian yang membahas topik ini dan memperdalam tentang ketajaman argumen tidak hanya sebatas kelengkapannya saja, selain itu juga dapat membahas mengenai kesalahan bernalar.

\section{DAFTAR PUSTAKA}

Keraf, G. 1992. Argumentasi dan Narasi. Jakarta: PT Gramedia.

Sugiyono. 2007. Metode Penelitian Pendidikan Pendekatan Kuantitatif, Kualitatif, dan $R$ \& $D$. Bandung: Alfabeta.

Toulmin, Stephen, Richard Rieke dan Allan Janik. 1984 An Introduction to reasoning. Canada: Macmilllan Publishing Company.

Weston, Anthony. 2007. Kaidah Berargumentasi. Yogyakarta: Pustaka Pelajar.

Yulistio, Didi. 2003. Bahasa Indonesia: Kemampuan Berbahasa Indonesia untuk Mahasiswa di perguruan Tinggi. Bengkulu: Lemlit Unib Press. 